\title{
Inflammation and lipid metabolism as a strong background connecting psoriasis and liver diseases
}

\section{Stan zapalny i metabolizm lipidów jako silne podłoże łączące łuszczycę oraz choroby wątroby}

Dorota Kozłowska, Hanna Myśliwiec, Iwona Flisiak

Department of Dermatology and Venereology, Medical University of Bialystok, Poland

Klinika Dermatologii i Wenerologii, Uniwersytet Medyczny w Białymstoku, Polska

\author{
CORRESPONDING AUTHOR/ \\ ADRES DO KORESPONDENCJI: \\ lek. Dorota Kozłowska \\ Klinika Dermatologii \\ i Wenerologii \\ Uniwersytet Medyczny \\ w Białymstoku \\ ul. Żurawia 14 \\ 15-540 Białystok \\ tel.: +48508182954 \\ e-mail: dorota.kozlowska@umb. \\ edu.pl
}

\begin{abstract}
Psoriasis is not an isolated pathology of the skin and joints, but is also characterized by multiple extracutaneous systemic manifestations. Beside the co-occurrence of obesity, arterial hypertension, dyslipidemia, and type 2 diabetes mellitus, there is a strong correlation with many liver disturbances. The most common liver comorbid disease coexisting with psoriasis is non-alcoholic fatty liver disease, which is a hepatic manifestation of metabolic syndrome. Both diseases share the same molecular mechanisms: chronic systemic inflammation, oxidative stress, disturbances of lipid metabolism, immune pathways and secretions of bioactive molecules. Additionally, patients with psoriasis have an increased risk of developing autoimmune liver disease and also liver cancer in comparison to the heathy population. Moreover, drugs used in treatment of psoriasis and psoriatic arthritis augment the hepatotoxic effect on the liver. The study below presents the most recent data on the liver diseases and their pathogenesis in patients with psoriasis.
\end{abstract}

\section{STRESZCZENIE}

Łuszczyca jest obecnie uważana nie tylko za chorobę skóry i stawów, charakteryzuje się także wieloma objawami ogólnoustrojowymi. Poza współwystępowaniem otyłości, nadciśnienia tętniczego, dyslipidemii, cukrzycy typu 2, istnieje silny związek między łuszczycą a zaburzeniami czynności wątroby. Najczęstszą chorobą współistniejącą z łuszczycą jest niealkoholowa stłuszczeniowa choroba wątroby, która stanowi wątrobową manifestację zespołu metabolicznego. Wspólnym podłożem obu schorzeń są te same mechanizmy molekularne: przewlekły, ogólnoustrojowy stan zapalny, stres oksydacyjny, zaburzenia metabolizmu lipidów, nieprawidłowe wspólne szlaki immunologiczne oraz wydzielanie cząsteczek bioaktywnych. U pacjentów z łuszczycą występuje większe ryzyko rozwoju autoimmunologicznych chorób wątroby, a także raka wątroby w porównaniu z populacją ogólną. Dodatkowo leki stosowane $\mathrm{w}$ leczeniu łuszczycy i łuszczycowego zapalenia stawów mogą mieć działanie hepatotoksyczne. W poniższym artykule przedstawiono najnowsze dane dotyczące chorób wątroby i ich patogenezy u pacjentów z łuszczycą. 
Key words: metabolic syndrome, psoriasis, inflammation, lipids, non-alcoholic fatty liver disease.

Słowa kluczowe: zespół metaboliczny, łuszczyca, stan zapalny, lipidy, niealkoholowa stłuszczeniowa choroba wątroby.

\section{INTRODUCTION}

Psoriasis is a chronic, immune-mediated inflammatory skin disease with a genetic predisposition, where Th1 and Th17 cell populations play a major role by producing a variety of pro-inflammatory cytokines $[1,2]$. Its prevalence is $2-3 \%$ of the population worldwide, ranging from $0.91 \%$ in the USA to $8.5 \%$ in Norway, which suggests approximately 125 million psoriatic patients worldwide [3,4].

Many population studies have confirmed a very strong association between psoriasis and metabolic syndrome including obesity, dyslipidemia, arterial hypertension and type 2 diabetes [5-7]. Moreover, numerous recent studies have also shown that psoriatic patients due to the course of the skin disease, taken drugs and also coexistence of various immunometabolic alterations are predisposed to the development of liver dysfunction. Based on the current literature we present clinical and molecular aspects of the influence of psoriasis on liver dysfunction.

\section{NON-ALCOHOLIC FATTY LIVER DISEASE}

Non-alcoholic fatty liver disease (NAFLD) is the most common cause of chronic liver disease in Western countries. Histological features of NAFLD consist of a wide spectrum of liver conditions ranging from mild steatosis, non-alcoholic steatohepatitis (NASH), to advanced fibrosis and cirrhosis. Lipid accumulation in the liver leads to lipotoxicity and consequently to mitochondrial dysfunction, oxidative stress and activate inflammatory pathways, which cause further liver damage $[8,9]$. The prevalence of NAFLD in the general population is approximately $30-40 \%$ in men and $15-20 \%$ in women $[10,11]$. Among psoriatic patients, the rate is even higher, ranging from $17 \%$ to $65 \%$ [3]. NASH is diagnosed in $20 \%$ of NAFLD patients and displays a greater tendency to evolve in psoriatic patients worldwide [12]. NAFLD may increase the risk of developing type 2 diabetes, cardiovascular disease (CVD) and chronic kidney diseases. The majority of death causes among NAFLD patients are attributed to CVD [13].

\section{WPROWADZENIE}

Łuszczyca jest przewlekłą, zapalną chorobą skóry, uwarunkowaną genetycznie, w której istotną rolę odgrywa populacja komórek Th1 i Th17, biorących udział w produkcji licznych cytokin prozapalnych [1, 2]. Schorzenie obejmuje 2-3\% populacji na świecie, od 0,91\% w USA do 8,5\% w Norwegii, co oznacza, że na łuszczycę choruje ok. 125 mln ludzi $[3,4]$.

$\mathrm{W}$ wielu badaniach populacyjnych potwierdzono bardzo silną zależność pomiędzy łuszczycą a zespołem metabolicznym, obejmującym m.in. otyłość, dyslipidemię, nadciśnienie tętnicze i cukrzycę typu 2 [5-7]. Według doniesień $z$ ostatnich lat wykazano, że pacjenci z łuszczycą - ze względu na przebieg choroby, przyjmowane leki oraz różnorodne współistniejące nieprawidłowości immunometaboliczne - charakteryzują się zwiększonym ryzykiem rozwoju zaburzeń czynności wątroby. Na podstawie aktualnego piśmiennictwa przedstawiamy kliniczne i molekularne zagadnienia dotyczące wpływu łuszczycy na upośledzenie czynności wątroby.

\section{NIEALKOHOLOWA STŁUSZCZENIOWA CHOROBA WATROBY}

Niealkoholowa stłuszczeniowa choroba wątroby (non-alcoholic fatty liver disease - NAFLD) jest najczęstszą przewlekłą chorobą wątroby w krajach Europy Zachodniej i USA. Obraz histologiczny NAFLD obejmuje szerokie spektrum nieprawidłowości od łagodnego stłuszczenia wątroby, niealkoholowego stłuszczeniowego zapalenia wątroby (non-alcoholic steatohepatitis - NASH) poprzez zaawansowane zwłóknienie i marskość wątroby. Odkładanie się lipidów w wątrobie prowadzi do lipotoksyczności, upośledzenia czynności mitochondriów i stresu oksydacyjnego, a także aktywuje szlaki zapalne, co wpływa na dalsze uszkodzenie tego narządu [8,9]. Szacuje się, że częstość występowania NAFLD w populacji ogólnej wynosi ok. 30-40\% u mężczyzn i 15$20 \%$ u kobiet $[10,11]$. Wśród pacjentów z łuszczycą odsetek ten jest jeszcze wyższy, waha się od $17 \%$ do $65 \%$ [3]. Niealkoholowe stłuszczeniowe zapalenie wątroby jest rozpoznawane u $20 \%$ pacjentów z NAFLD i jest częstsze u chorych ze współistniejącą łuszczycą [12]. Ponadto NAFLD może nasilać ryzyko rozwoju cukrzycy typu 2, 


\section{CONNECTION BETWEEN PSORIASIS AND NAFLD}

Recent studies suggest that psoriasis can trigger liver disease independently of metabolic syndrome components or other cofactors, such as viral hepatitis or congenital errors of metabolism. This relationship also appears to be independent of the intake of hepatotoxic anti-psoriatic drugs [14].

Psoriatic patients more often can develop advanced forms of NAFLD than healthy people $[15,16]$. Gisondi et al. found in their study on a group of 130 patients with plaque-type psoriasis that prevalence of NAFLD was almost two times higher among psoriatic individuals than among healthy controls ( $47 \%$ vs. $28 \%$ ). The authors emphasize that none of the patients received potentially hepatotoxic drugs [17]. Another study on a group of 250 psoriatic adults showed that the prevalence of NAFLD was 45.2\% [18]. Van der Voort et al. found in their study on elderly individuals that they were $70 \%$ more likely to have NAFLD than those without psoriasis, independently of metabolic syndrome and other common NAFLD risk factors [19]. Another study showed that $47 \%$ of patients with psoriasis or psoriatic arthritis were diagnosed with NAFLD, while $22 \%$ of them had NASH [20].

Severe course of psoriasis significantly increases the risk of NAFLD. In the case of psoriatic arthritis this risk may be even higher [21, 22]. Psoriatic patients with NAFLD have a higher PASI (Psoriasis Area Severity Index) score, serum concentration of $\mathrm{C}$-reactive protein (CRP) and interleukin-6 (IL-6) than patients with psoriasis alone $[17,23,24]$. Psoriatic patients with diagnosed NAFLD are more likely to have metabolic syndrome than those with psoriasis alone and tended to have higher frequency of abnormal liver function test (LFT) results and higher levels of serum lipids [21]. People with confirmed NAFLD and concomitant psoriasis were more prone to the development of liver fibrosis than non-psoriatic controls $[25,26]$.

The NAFLD fibrosis score (NFS) was developed a few years ago to assess liver fibrosis among patients with diagnosed NAFLD, which can also be used in diagnosis liver disturbances among psoriatic patients. This method is also useful as a predictor of higher risk of overall mortality, cardiac complications, and liver complications among patients with NAFLD [27]. Patients with an NFS $<-1.455$ can safely be followed up in primary care clinics. Patients with a score $>0.675$ are highly suspected to have liver fibrosis.

\section{SYSTEMIC INFLAMMATORY PROCESS - POTENTIAL LINK BETWEEN PSORIASIS AND NAFLD}

Psoriasis and NAFLD share multiple inflammatory and cytokine-mediated pathways. The mecha- chorób sercowo-naczyniowych (cardiovascular disease CVD) i przewlekłych chorób nerek. Większość zgonów wśród pacjentów z NAFLD jest spowodowana CVD [13].

\section{ZALEŻNOŚĆ MIĘDZY ŁUSZCZYCA A NAFLD}

Według doniesień z ostatnich lat łuszczyca może wpływać na rozwój schorzeń wątroby niezależnie od współistniejących komponentów zespołu metabolicznego, a także innych czynników, takich jak wirusowe zapalenie wątroby czy wrodzone zaburzenia metaboliczne. Związek ten wydaje się również niezależny od przyjmowania leków przeciwłuszczycowych o właściwościach hepatotoksycznych [14].

U pacjentów z łuszczycą częściej występują zaawansowane postacie NAFLD w porównaniu ze zdrową populacją $[15,16]$. Gisondi i wsp. w badaniu obejmującym 130 pacjentów z łuszczycą plackowatą wykazali, że częstość występowania NAFLD jest niemal dwukrotnie wyższa u chorych na łuszczycę w porównaniu ze zdrową grupą kontrolną (47\% vs $28 \%$ ). Autorzy podkreślają, że żaden z pacjentów nie przyjmował leków o potencjalnym działaniu hepatotoksycznym [17]. W innym badaniu, przeprowadzonym w grupie 250 dorosłych osób z łuszczycą, częstość występowania NAFLD wyniosła $45,2 \%$ [18]. Van der Voort i wsp. w analizach prowadzonych u osób z łuszczycą w podeszłym wieku wykazali, że prawdopodobieństwo wystąpienia NAFLD w tej grupie jest o 70\% wyższe niż u osób niechorujących na łuszczycę, niezależnie od wspóistniejących wykładników zespołu metabolicznego i innych głównych czynników ryzyka rozwoju NAFLD [19]. W innym badaniu u 47\% pacjentów z łuszczycą lub łuszczycowym zapaleniem stawów rozpoznano NAFLD, a u 22\% z nich zdiagnozowano NASH [20].

Ciężki przebieg łuszczycy istotnie zwiększa ryzyko wystąpienia NAFLD. W przypadku współistnienia łuszczycowego zapalenia stawów ryzyko jest jeszcze wyższe [21, 22]. U pacjentów z łuszczycą i współistniejącą NAFLD stwierdzono wyższy wskaźnik nasilenia łuszczycy PASI (Psoriasis Area and Severity Index) oraz wyższe stężenie białka C-reaktywnego (C-reactive protein - CRP) i interleukiny 6 (IL-6) w surowicy $\mathrm{w}$ porównaniu $\mathrm{z}$ pacjentami bez współistniejącej choroby wątroby $[17,23$, 24]. U chorych z łuszczycą i NAFLD częściej występuje zespół metaboliczny w porównaniu z chorymi $\mathrm{z}$ prawidłową funkcją wątroby. Ponadto częściej stwierdza się $\mathrm{u}$ nich nieprawidłowe wyniki prób czynnościowych wątroby (liver function test - LFT) i wyższe stężenie lipidów w surowicy [21]. Wykazano, że pacjenci z łuszczycą i współistniejącą NAFLD są w konsekwencji bardziej podatni na rozwój zwłóknienia tego narządu w porównaniu ze zdrową populacją $[25,26]$.

Wskaźnik zwłóknienia wątroby NFS (NAFLD fibrosis score) to nieinwazyjny wskaźnik umożliwiający ocenę stopnia zwłóknienia wątroby u pacjentów z NAFLD, 
nisms which underly the association between psoriasis and NAFLD are multifactorial and involve both genetic and environmental factors, often overlapping with metabolic abnormalities. Chronic, low-grade inflammation seems to be the most important etiological factor. Many proinflammatory cytokines such as IL-1, IL-6, and tumor necrosis factor $\alpha$ (TNF- $\alpha$ ) are common causes of metabolic inflammation for both diseases; they are over-produced in the psoriatic skin, affecting the deterioration of the skin condition and also contribute to development of insulin resistance, which as a consequence promotes liver steatosis. IL6 is fundamental in the progression of NAFLD toward liver cirrhosis, via NASH [28]. TNF- $\alpha$ and IL-6 not only cause proliferation and differentiation of keratinocytes but also increase insulin resistance and promote proinflammatory cytokine release [29]. IL-17 and TNF- $\alpha$, which are responsible for vascular remodeling in psoriatic skin, also can cause steatosis and fibrosis of the liver [3]. Such correlations may explain the "multiple hit model", the hypothesis proposed in pathophysiology of NAFLD as multistep liver injury [30].

An additional mechanism which plays an important role in the development of NAFLD among psoriatic patients is the visceral adipose tissue, which may release increased amounts of various hormones and pro-inflammatory adipocytokines (including TNF- $\alpha$, IL-6, IL-17, leptin, visfatin, and resistin), and decreased amounts of adiponectin [31-33]. TNF- $\alpha$ produced by visceral tissue may exacerbate hepatic insulin resistance by interfering with insulin receptor signal transduction pathways and also inhibits adipocyte production of adiponectin. Low levels of adiponectin result in decreased hepatic insulin sensitivity, hepatic free fatty acid (FFA) oxidation and increased hepatic FFA uptake [31].

Above adipocytokines cause secretion of hepatokines by the liver, which act similarly to them, affecting lipid and glucose metabolism and promoting liver fibrogenesis. This imbalance of pro- and anti-inflammatory adipocytokines is a typical phenomenon among psoriatic patients (table 1).

\section{DISTURBANCES IN LIPID METABOLISM - SECOND POTENTIAL LINK BETWEEN PSORIASIS AND LIVER DYSFUNCTION}

The skin is characterized by active lipid metabolism and constitutes a source of numerous lipid mediators [34]. It has an impact on the course of psoriasis and also leads to the occurrence of systemic diseases, including liver metabolism dysregulation.

In psoriasis and psoriatic arthritis patients numerous lipid changes have been found, such as increased serum concentrations of total cholesterol który również może mieć znaczenie w diagnostyce chorób wątroby u pacjentów z łuszczycą. Powyższa metoda może być ponadto wykorzystywana jako predyktor wyższego ryzyka śmiertelności, powikłań kardiologicznych oraz powikłań wątrobowych u pacjentów z NAFLD [27]. Leczenie pacjentów, u których wartość wskaźnika NFS wynosi <-1,455, może być bezpiecznie prowadzone w placówkach podstawowej opieki zdrowotnej. U pacjentów z wynikiem > 0,675 istnieje duże ryzyko zwłóknienia wątroby.

\section{OGÓLNOUSTROJOWY PROCES ZAPALNY - POTENCJALNA ZALEŻNOŚĆ POMIĘDZY ŁUSZCZYCA A NAFLD}

Łuszczyca i NAFLD dzielą wiele wspólnych szlaków zapalnych mediowanych przez cytokiny prozapalne. Mechanizmy leżące $u$ podstaw zależności między tymi schorzeniami są wieloczynnikowe. Obejmują zarówno czynniki genetyczne, jak i środowiskowe, które często pokrywają się z istniejącymi zaburzeniami metabolicznymi. Prawdopodobnie najważniejszym czynnikiem etiologicznym jest ogólnoustrojowy przewlekły stan zapalny. Liczne cytokiny prozapalne, m.in. IL-1, IL-6 oraz czynnik martwicy nowotworu $\alpha$ (tumor necrosis factor $\alpha-\mathrm{TNF}-\alpha$ ), często prowadzą do rozwoju metabolicznie wywołanego stanu zapalnego w przebiegu obu chorób. W skórze zmienionej łuszczycowo następuje nadmierna produkcja powyższych cytokin, co implikuje pogorszenie stanu skóry, wpływa na rozwój insulinooporności, a także stłuszczenie wątroby. Interleukina 6 odgrywa kluczową rolę w progresji NAFLD oraz wpływa na przyspieszenie marskości wątroby w przebiegu NASH [28]. TNF- $\alpha$ i IL-6 nie tylko indukują proliferację i różnicowanie keratynocytów, lecz także nasilają insulinooporność i sprzyjają uwalnianiu cytokin prozapalnych [29]. IL-17 i TNF- $\alpha-$ cytokiny odpowiedzialne za przebudowę naczyń w skórze objętej procesem łuszczycowym - mogą powodować stłuszczenie i zwłóknienie wątroby [3]. Opisane powyżej korelacje mogą częściowo wyjaśniać tzw. hipotezę wielu przyczyn (multiple hit model), która opisuje patofizjologię NAFLD jako wieloetapowe uszkodzenie wątroby [30].

Dodatkowy mechanizm, który odgrywa istotną rolę w rozwoju NAFLD u pacjentów z łuszczycą, obejmuje trzewną tkankę tłuszczową, w której może dochodzić do wzmożonej produkcji i uwalniania różnych hormonów i adipocytokin prozapalnych (w tym TNF- $\alpha$, IL-6, IL-17, leptyny, wisfatyny i rezystyny) oraz zmniejszonego wytwarzania adiponektyny [31-33]. Czynnik TNF- $\alpha$ wytwarzany w tkance trzewnej może promować insulinooporność wątrobową poprzez zakłócanie szlaków przekaźnictwa sygnałów przez receptor insulinowy, a także hamuje wytwarzanie adiponektyny przez adipocyty. Niskie stężenie adiponektyny powoduje zmniejszenie insulinowrażliwości wątroby, utlenianie wolnych 
Table I. Levels of adipokines and hepatokines and their role in psoriasis and non-alcoholic fatty liver disease

Tabela I. Stężenie adipokin i hepatokin oraz ich rola w łuszczycy i niealkoholowej stłuszczeniowej chorobie wątroby

\begin{tabular}{|c|c|c|c|}
\hline $\begin{array}{l}\text { Cytokines/ } \\
\text { Cytokiny }\end{array}$ & $\begin{array}{l}\text { Level/ } \\
\text { Poziom }\end{array}$ & Psoriasis/Łuszczyca & NAFLD/NAFLD \\
\hline \multicolumn{4}{|c|}{ Pro-inflammatory adipokines/Adipokiny prozapalne: } \\
\hline TNF- $\alpha$ & $\uparrow$ & $\begin{array}{l}\uparrow \text { Keratinocyte proliferation/^ Proliferacja keratynocytów } \\
\text { Pro-inflammatory cytokines/Cytokiny prozapalne } \\
\text { Angiogenesis/Angiogeneza }\end{array}$ & $\begin{array}{l}\uparrow \text { Hepatic fibrogenesis/ } \uparrow \text { Fibrogeneza } \\
\text { wątrobowa } \\
\text { Contributes to insulin resistance/Przyczynia } \\
\text { się do insulinooporności }\end{array}$ \\
\hline IL-I & $\uparrow$ & 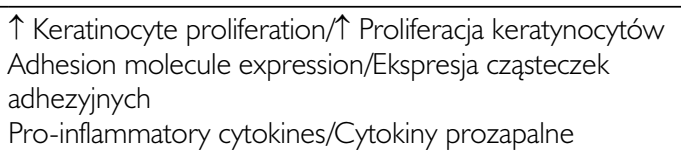 & $\begin{array}{l}\uparrow \text { Activation of MAP and ERG pathways/ } \\
\uparrow \text { Aktywacja szlaków MAP i ERG }\end{array}$ \\
\hline IL-6 & $\uparrow$ & 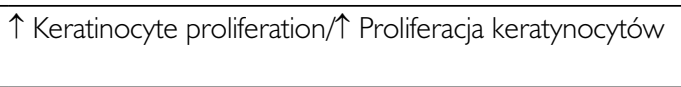 & $\begin{array}{l}\uparrow \text { Contributes to insulin resistance/ } \\
\uparrow \text { Przyczynia się do insulinooporności }\end{array}$ \\
\hline Leptin/Leptyna & $\uparrow$ & 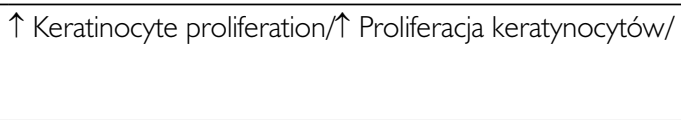 & $\begin{array}{l}\text { } \uparrow \text { Leptin resistance, contributes to hepatic } \\
\text { fibrogenesis/ } \uparrow \text { Oporność na leptynę, } \\
\text { przyczynia się do fibrogenezy wątrobowej }\end{array}$ \\
\hline $\begin{array}{l}\text { Resistin/ } \\
\text { Rezystyna }\end{array}$ & $\uparrow$ & $\begin{array}{l}\text { ThI response, angiogenesis/Odpowiedź Thl, } \\
\text { angiogeneza }\end{array}$ & $\uparrow$ Insulin resistance $/ \uparrow$ Insulinooporność \\
\hline Visfatin/Wisfatyna & $\uparrow$ & 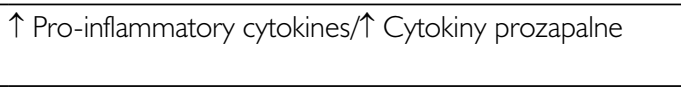 & $\begin{array}{l}\text { 个 Contributes to insulin resistance/ } \uparrow \\
\text { Przyczynia się do insulinooporności }\end{array}$ \\
\hline Ghrelin/Grelina & $\uparrow$ & & $\begin{array}{l}\uparrow \text { Negatively correlated to TNF- } \alpha / \uparrow \text { Ujemna } \\
\text { korelacja z TNF- } \alpha\end{array}$ \\
\hline \multicolumn{4}{|c|}{ Anti-inflammatory adipokines/Adipokiny przeciwzapalne: } \\
\hline $\begin{array}{l}\text { Adiponectin/ } \\
\text { Adiponektyna }\end{array}$ & $\downarrow$ & $\downarrow$ Anti-inflammatory cytokines/ $\downarrow$ Cytokiny przeciwzapalne & $\downarrow$ Insulin sensitivity/ $\downarrow$ Insulinowrażliwość \\
\hline \multicolumn{4}{|c|}{ Pro-inflammatory hepatokines/Hepatokiny prozapalne: } \\
\hline CRP & $\uparrow$ & & $\begin{array}{l}\uparrow \text { Hepatic fibrogenesis/ } \uparrow \text { Fibrogeneza } \\
\text { wątrobowa }\end{array}$ \\
\hline $\mathrm{TNF}-\alpha$ & $\uparrow$ & & $\begin{array}{l}\uparrow \text { Hepatic fibrogenesis/ } \uparrow \text { Fibrogeneza } \\
\text { wątrobowa }\end{array}$ \\
\hline IL-6 & $\uparrow$ & & $\begin{array}{l}\uparrow \text { Hepatic fibrogenesis } / \uparrow \text { Fibrogeneza } \\
\text { wątrobowa }\end{array}$ \\
\hline
\end{tabular}

MAP - mitogen-activated protein; ERG - ergosterol. Data based on: Prussick R.B., Miele L.: Nonalcoholic fatty liver disease in patients with psoriasis: a consequence of systemic inflammatory burden? Br J Dermatol 2018, 179, 16-29.

MAP - kinaza aktywowana miogenami, ERG - ergosterol. Dane oparte na: Prussick R.B., Miele L.: Nonalcoholic fatty liver disease in patients with psoriasis: a consequence of systemie inflammatory burden? Brit J Dermatol 2018, 179, 16-29.

(TC), low-density lipoprotein cholesterol (LDL-C), triglycerides (TG), and lipoprotein Lp(a), and decreased concentrations of high-density lipoprotein cholesterol (HDL-C) [34-36]. Those individuals have dysfunctional LDLs or HDLs, low-volume LDLs and LDL efflux disturbances. Furthermore, patients with psoriatic arthritis seem to have apolipoprotein or oxidized low-density lipoprotein (oxLDL) abnormalities, and its severity could be related to the concentration of small, dense LDLs [36].

\section{Sphingolipids}

Sphingolipids are a group of lipids which contain the sphingoid base, which is formed by the condensation of an amino acid and a fatty acid. The sphingoid bases are enzymatically modified, generating wide range of biologically active sphingolipids, includ- kwasów tłuszczowych (free fatty acid - FFA) w wątrobie oraz nasilony ich wychwyt w wątrobie [31].

Powyższe adipocytokiny indukują wydzielanie hepatokin przez wątrobę, które mają podobne do nich działanie, co wpływa na metabolizm lipidów i glukozy oraz sprzyja fibrogenezie wątroby. Ten brak równowagi między pro- i przeciwzapalnymi adipocytokinami jest również typowym zjawiskiem obserwowanym u pacjentów z łuszczycą (tab. 1).

\section{ZABURZENIA METABOLIZMU LIPIDÓW - DRUGA POTENCJALNA ZALEŻNOŚĆ MIĘDZY ŁUSZCZYCA A UPOŚLEDZENIEM CZYNNOŚCI WALTROBY}

Skóra charakteryzuje się aktywnym metabolizmem lipidów i jest źródłem licznych mediatorów lipidowych 
ing ceramides (CER), sphingomyelin, sphingosine1-phosphate (S1P), ceramide-1-phosphate, and glycosphingolipids. Generally, they play a significant role in cell homeostasis and may serve as structural and signaling molecules or be transported to plasma lipoproteins [37].

\section{Sphingolipids in skin disorders}

CER are the most important epidermal sphingolipids and constitute about $50 \%$ of intercellular lipids by mass. CER are responsible for the epidermal skin barrier function and the prevention of transepidermal water loss (TEWL). They regulate different processes such as proliferation, differentiation and apoptosis of keratinocytes. Moreover, CER participate in cell cycle arrest as well as inflammatory and stress responses [38]. In many dermatological diseases, including psoriasis, concentration of ceramides in the skin and their circulating levels in serum differ from healthy people. Reduced CER levels in psoriatic skin is associated with their anti-apoptotic effect with concomitant pro-proliferative action, which may explain the occurrence of psoriatic papules [37].

\section{Sphingolipids in liver disturbances}

Recent studies suggest that CER are the main molecules among all sphingolipids involved in lipotoxicity during NAFLD $[39,40]$. They are also considered as a major mediator of lipid-induced insulin resistance and other cellular processes strongly linked to NAFLD, such as fat accumulation, oxidative stress, inflammation and cell death [30]. Some CER are particularly involved in the pathogenesis of liver dysfunction. The study of Maldonado-Hernandez et al. showed the association of CER with hepatic steatosis and the serum concentration of all CER correlated directly with alanine aminotransferase (ALT) concentration. Additionally the authors highlighted that myristic ceramide (C14:0) could be a novel biomarker of hepatosteatosis independent of obesity [41]. In turn, long chain CER such as palmitic (CER 16:0) and stearic (CER 18:0) are believed to be the main molecules involved in insulin resistance and hepatic steatosis.

\section{Free fatty acids}

Free fatty acids (FFA) are not only a source of energy and components of cell membranes, but also regulate immune responses and other vital cellular functions. Depending on their length they can be pro- or anti-inflammatory molecules [35]. Patients with coexisting metabolic diseases had significantly higher total concentrations of FA, saturated fatty acids (SFA), and monounsaturated fatty acids (MUFA) and a higher proportion of SFA to unsaturated fatty acids (UFA). The SFA/UFA index increased with the duration of the disease, which may be further proof
[34]. Ma to wpływ na przebieg łuszczycy, a także prowadzi do rozwoju chorób ogólnoustrojowych, w tym zaburzenia regulacji procesów metabolicznych $\mathrm{w}$ wątrobie.

U pacjentów z łuszczycą i łuszczycowym zapaleniem stawów stwierdzono liczne zaburzenia profilu lipidowego w surowicy, takie jak podwyższone stężenie cholesterolu całkowitego (total cholesterol - TC), frakcji lipoprotein o niskiej gęstości (low-density lipoprotein cholesterol - LDL-C), trójglicerydów (TG) i lipoproteiny Lp(a) oraz obniżone stężenia frakcji lipoprotein o wysokiej gęstości (high-density lipoprotein cholesterol - HDL-C) [34-36]. W tej populacji stwierdza się także dysfunkcyjne cząsteczki lipoprotein LDL oraz HDL, LDL o małej objętości, a także zaburzenia wypływu LDL. U pacjentów z łuszczycowym zapaleniem stawów może występować zwiększone stężenie apolipoprotein oraz utlenione lipoproteiny o niskiej gęstości (oxLDL), a nasilenie choroby można powiązać z nieprawidłowym poziomem tzw. małych, gęstych LDL [36].

\section{Sfingolipidy}

Sfingolipidy są grupą lipidów, których szkielet budowy stanowi sfingozyna powstała w wyniku kondensacji aminokwasu z kwasem tłuszczowym. Sfingozyna jest modyfikowana enzymatycznie, co generuje całą gamę aktywnych biologicznie sfingolipidów, do których należą m.in. ceramidy (CER), sfingomielina, sfingozyno-1-fosforan (sphinosine-1-phosphate - S1P), ceramido-1-fosforan i glikosfingolipidy. Zasadniczo odgrywają one istotną rolę $\mathrm{w}$ homeostazie komórkowej i mogą pełnić funkcję jako cząsteczki strukturalne i sygnałowe, a także być transportowane do lipoprotein osocza [37].

\section{Sfingolipidy w schorzeniach skóry}

Do najważniejszych sfingolipidów obecnych w naskórku należą CER, które stanowią ok. $50 \%$ wszystkich lipidów w obrębie korneocytów. Ceramidy odpowiadają za tworzenie naskórkowej bariery ochronnej skóry i stanowią ochronę przed przeznaskórkową utratą wody (transepidermal water loss - TEWL). Ceramidy biorą również udział w regulacji różnych procesów komórkowych, takich jak proliferacja, różnicowanie i apoptoza keratynocytów, a także uczestniczą w reakcjach zapalnych i stresowych [38]. W przebiegu wielu schorzeń dermatologicznych, m.in. łuszczycy, stężenie CER w skórze oraz ich stężenie w surowicy różni się w stosunku do osób zdrowych. Zmniejszone stężenie CER w skórze zmienionej łuszczycowo wiąże się z ich działaniem antyapoptotycznym i jednoczesną aktywnością pro-proliferacyjną, co może częściowo wyjaśniać powstawanie grudek łuszczycowych [37].

\section{Sfingolipidy w zaburzeniach czynności wątroby}

Ostatnie doniesienia sugerują, że CER, spośród wszystkich sfingolipidów, odgrywają główną rolę w promowaniu lipotoksyczności w przebiegu NAFLD $[39,40]$. 
that comorbidities associated with psoriasis develop directly with the duration of psoriasis. FFA, especially SFA, are believed to have a negative influence on skin [42]. Diet-delivered SFA are responsible for exacerbation of skin lesions and intensify the severity of the disease.

Myristic acid, which belongs to the SFA group, might be an indicator of liver dysfunction [42]. Furthermore, numerous studies suggest their crucial role in liver damage. They are believed to be one of the risk factors of NAFLD and its complications. On the other hand, UFA have a beneficial effect on the skin and are also known as protectors against the development of autoimmune and metabolic disorders. The supplementation of UFA exerts a beneficial effect on psoriatic lesions [34, 43]. n-6 polyunsaturated FA (n-6 PUVA), marine derived n-3 PUFA and MUFA due to their anti-inflammatory effect are believed to be protective factors for the risk of development of metabolic syndrome. Supplementation of n-3 PUFA also reduces pro-inflammatory cytokine levels, improves glycemia and has hypolipidemic, antithrombotic, antiarrhythmic and vasodilatory properties [44, 45]. Moreover, the Mediterranean diet, rich in MUFA, reduces liver steatosis and improves insulin sensitivity in an insulin-resistant population with NAFLD [44]. These data indicate that FFA profile alteration, especially imbalance between SFA and UFA, implies further systemic metabolic disturbances and can trigger liver disturbances among psoriatic patients.

\section{Fatty acid binding proteins}

Fatty acid binding proteins (FABPs) display high affinity for binding long chain fatty acids. FABPs are believed to be a central player in mediating metabolic balance and lipid-mediated responses through the regulation of diverse lipid signals [46].

Different components of the FABP family are expressed most abundantly in organs involved in active lipid metabolism. FABP isoforms are believed to be a useful tool of organ damage prediction and they play an important role in the development of a number of immunometabolic diseases [47-49]. For instance, heart-type FABP (FABP3) is a sensitive marker of acute myocardial infarction and predictor of heart failure among patients with coexisting metabolic syndrome, and its level is increased in diabetes mellitus. Adipocyte fatty acid binding protein (FABP4) is known due to its association with the development of components of metabolic syndrome. This protein is elevated in patients with obesity, diabetes mellitus, NAFLD and CVD [47].

Epidermal FABP, also known as E-FABP, psoriasis-associated FABP or FABP5 is highly expressed in skin epidermal cells, vessel endothelial cells and also organ epithelial cells. Moreover, E-FABP exists in
Są również uznawane za głównego mediatora insulinooporności indukowanej przez lipidy i innych procesów komórkowych wpływających na rozwój NAFLD, takich jak akumulacja lipidów, stres oksydacyjny, stan zapalny i apoptoza [30]. Niektóre CER mają szczególnie istotne znaczenie w patogenezie zaburzeń czynności wątroby. Maldonado-Hernandez i wsp. w swojej pracy wykazali zależność pomiędzy stężeniem CER a stłuszczeniem wątroby, a także bezpośrednią korelację pomiędzy stężeniem wszystkich CER w surowicy a stężeniem aminotransferazy alaninowej (alanine aminotransferase - ALT). Dodatkowo autorzy stwierdzili, że ceramid mirystynowy (C14:0) może być wykorzystywany jako biomarker stłuszczenia wątroby niezależnie od współistniejącej otyłości [41]. Ponadto wykazano, że CER zbudowane z kwasów długołańcuchowych, m.in. kwasu palmitynowego (CER 16:0) i stearynowego (CER 18:0), są głównymi cząsteczkami uczestniczącymi w rozwoju insulinooporności i stłuszczenia wątroby.

\section{Wolne kwasy tłuszczowe}

Wolne kwasy tłuszczowe (free fatty acids - FFA) są nie tylko źródłem energii i składnikiem błon komórkowych, lecz także regulują odpowiedź immunologiczną i pełnią inne istotne funkcje komórkowe. W zależności od długości mogą mieć działanie pro- lub przeciwzapalne [35]. U pacjentów ze współistniejącymi chorobami metabolicznymi obserwowano istotnie wyższe całkowite stężenie kwasów tłuszczowych (FFA), a także stężenie nasyconych kwasów tłuszczowych (saturated fatty acids - SFA), jednonienasyconych kwasów tłuszczowych (monounsaturated fatty acids - MUFA), a także stosunek kwasów SFA do nienasyconych kwasów tłuszczowych (unsaturated fatty acids - UFA). Wykazano, że stosunek SFA/UFA wzrasta wraz z czasem trwania choroby, co może być kolejnym dowodem na to, że rozwój chorób współistniejących z łuszczycą zależy od czasu trwania łuszczycy. Uważa się, że FFA, zwłaszcza SFA, mają niekorzystny wpływ na skórę [42]. SFA dostarczane do organizmu w diecie odpowiadają za zaostrzenie zmian skórnych i większe nasilenie choroby.

Kwas mirystynowy, należący do grupy SFA, może być wskaźnikiem upośledzenia czynności wątroby [42]. Liczne badania potwierdziły również kluczową rolę innych SFA w uszkodzeniu tego narządu. Uważa się, że SFA stanowią jeden z czynników ryzyka rozwoju NAFLD i jej powikłań. Z kolei UFA korzystnie oddziałują na skórę oraz chronią przed rozwojem zaburzeń autoimmunologicznych i metabolicznych. Suplementacja UFA przyczynia się do poprawy zmian skórnych [34, 43]. Udowodniono, że n-6 wielonienasycone kwasy tłuszczowe (n-6 PUFA), pochodzące z ryb morskich kwasy, n-3 PUFA i MUFA dzięki działaniu przeciwzapalnemu stanowią czynnik ochronny przed rozwojem zespołu metabolicznego. Suplementacja n-3 PUFA redukuje również stężenie cytokin prozapalnych, poprawia glikemię oraz 
various types of immune cells. This wide expression pattern suggests that E-FABP plays a crucial role in maintaining cellular basic energy metabolism, thereby contributing to epithelial integrity and immune cell functions [46]. Those proteins are overexpressed in psoriatic lesions and also play a role in regulating insulin sensitivity [47].

Liver FABP (L-FABP, FABP1) is most abundant in liver cytoplasm, but it is also expressed in several other tissues, such as the intestine, pancreas, kidney, lung and stomach [50]. It is believed to take part in systemic metabolism and to be an early biomarker of acute kidney injury or chronic kidney disease, and lung damage, or a promising indicator to detect NAFLD. Baran et al. in their study observed a significantly increased level of FABP1 among psoriatic patients in comparison to healthy controls [48]. Interestingly, FABP1 concentration significantly decreased after 12 weeks of systemic treatment with methotrexate (MTX) or acitretin. This study shows that FABP1 might serve as a biomarker of psoriasis, play a role as a potential link between skin disease and its cardiometabolic comorbidities and also may have additional value in assessing the response of psoriatic treatment [48].

\section{LIVER DYSFUNCTION INDUCED BY ANTIPSORIATIC TREATMENT}

Drug-induced liver injury is the main cause of emergency liver transplantation and its manifestation can range from asymptomatic elevation of liver enzymes to acute liver failure [3]. Associated liver diseases among psoriatic patients limit therapeutic options and necessitate careful monitoring. Some systemic drugs may have a negative influence on liver function. The increased level of liver enzymes among psoriatic patients is associated in $57 \%$ of cases with liver toxic drugs and in $22 \%$ with NAFLD [51].

One of the most common side effects of using MTX is its hepatotoxicity [52]. The risk of liver dysfunction is low among patients without concomitant liver diseases (such as hepatitis B or C), alcohol abuse or taking other hepatotoxic drugs [52]. MTX rarely causes clinically significant hepatotoxicity and in most patients liver enzymes are only slightly elevated [53]. However, treatment with MTX of patients with obesity, type 2 diabetes and NAFLD requires special care because of the high risk of drug-induced liver fibrosis. This risk is much higher among psoriatic patients with metabolic comorbidities compared to patients with psoriasis alone [52]. Interestingly, the risk of liver hepatotoxicity and liver fibrosis is more relevant among psoriatic patients than individuals with działa hipolipemicznie, przeciwzakrzepowo, antyarytmicznie i ma właściwości wazodylatacyjne [44, 45]. Dieta śródziemnomorska, która charakteryzuje się wysoką zawartością MUFA, hamuje stłuszczenie wątroby i zwiększa insulinowrażliwość u osób z NAFLD [44].

Dane te wskazują, że zmiany w profilu FFA, zwłaszcza zaburzenie równowagi między SFA i UFA, indukują kolejne ogólnoustrojowe zaburzenia metaboliczne, co z kolei może implikować rozwój zaburzeń wątroby u pacjentów chorujących na łuszczycę.

\section{Białka wiążące kwasy tłuszczowe}

Białka wiążące kwasy tłuszczowe (fatty acid binding proteins - FABPs) wykazują wysokie powinowactwo do wiązania długołańcuchowych kwasów tłuszczowych. Uważa się, że FABP są głównym czynnikiem pośredniczącym w utrzymywaniu równowagi metabolicznej i reakcji zależnych od lipidów poprzez regulację różnych sygnałów lipidowych [46].

Białka z rodziny FABP ulegają ekspresji głównie w narządach uczestniczących w czynnym metabolizmie lipidów. Wykazano także, że izoformy FABP są przydatnym czynnikiem prognostycznym uszkodzenia narządów i mają duże znaczenie w rozwoju wielu chorób o podłożu immunometabolicznym [47-49]. Sercowe białko wiążące kwasy tłuszczowe (heart- FABP, H-FABP, $F A B P 3)$ jest czułym markerem ostrego zawału mięśnia sercowego i predyktorem niewydolności serca u pacjentów ze współistniejącym zespołem metabolicznym, a jego stężenie wzrasta u osób chorych na cukrzycę. Adipocytowe białko wiążące kwasy tłuszczowe (adipocyte $F A B P, A-F A B P, F A B P 4)$ wykazuje zależność z rozwojem składowych zespołu metabolicznego. Stężenie tego białka jest podwyższone u pacjentów z otyłością, cukrzycą, NAFLD i CVD [47].

Naskórkowe białko wiążące kwasy tłuszczowe, określane jako E-FABP - FABP związane z łuszczycą lub FABP5, ulega wzmożonej ekspresji w komórkach naskórka, komórkach śródbłonka naczyń, a także w komórkach nabłonka innych narządów oraz komórek układu odpornościowego. Tak szeroki wzór ekspresji wskazuje, że E-FABP odgrywa istotną rolę $\mathrm{w}$ zachowaniu podstawowego metabolizmu energetycznego komórek, co przyczynia się do podtrzymywania integralności nabłonka i czynności komórek odpornościowych [46]. Białka te ulegają nadekspresji w zmianach łuszczycowych, a także biorą udział w regulacji insulinowrażliwości [47].

Wątrobowe białko wiążące kwasy tłuszczowe (liver FABP, L-FABP, FABP1) występuje w największych ilościach w cytoplazmie wątroby, ale ulega również ekspresji w innych tkankach, m.in. w jelitach, trzustce, nerkach, płucach i żołądku [50]. Uważa się, że bierze udział w ogólnoustrojowych procesach metabolicznych, a także jest wczesnym biomarkerem ostrego uszkodzenia nerek, przewlekłej choroby nerek i uszkodzenia płuc. Wykazano, że FABP1 może być również obiecującym 
rheumatoid arthritis due to their greater propensity to metabolic syndrome [54].

Acitretin may also have a hepatotoxic influence on the liver, especially among patients with alcohol abuse or taking other hepatotoxic drugs [52]. Acitretin is a hyperlipidemic drug causing alteration in hepatic biochemistry in $25 \%$ of patients [26]. Hepatotoxicity caused by cyclosporin A is very rare [53]. However, it should be carefully used among psoriatic patients with coexisting metabolic disturbances. Cyclosporin A may exacerbate arterial hypertension, and it can worsen type 2 diabetes and predispose to atherogenic dyslipidemia and hyperuricema [55]. Both acitretin and ciclosporin are associated with an increased level of cholesterol and triglycerides and in addition acitretin is associated with triglyceridemia [9].

Fumaric acid esters (FAE) and apremilast are believed to have no hepatotoxic effects on the liver. Adverse events during treatment with fumaric acid esters are common and are reported in up to two thirds of all patients. The most common side effects are gastrointestinal symptoms which include abdominal pain, diarrhea, nausea and malaise. Rarely, moderate elevations of liver enzymes and bilirubin can be observed [56].

Biological agents generally have no negative influence on metabolic parameters and level of liver enzymes in serum [9]. Anti-TNF- $\alpha$ inhibitors do not cause clinically significant deteriorations in the lipid profile and they reduce the risk of developing type 2 diabetes. Campanati et al. found in their study of 89 individuals significant reduction in the aspartate transferase (AST)/alanine transferase (ALT) ratio, CRP serum concentration, and fasting insulin levels after 24 weeks of treatment with etanercept [57]. Another study showed that etanercept caused significant decrease of fasting glucose after 6 months of treatment. The lipid profile in serum during this treatment remained unchanged [58]. However, liver toxicity has been observed in some clinical studies of patients with psoriasis treated with this agent. Elevated levels of AST and ALT were observed in up to $8 \%$ of patients [59] Data from 3 randomized controlled trials over 52 weeks of treatment with anti-interleukin-17 monoclonal antibody showed stable levels of liver enzymes (ALT and AST). Secukinumab according to the current literature has no impact on lipid parameters, including TG, cholesterol, HDL and LDL [60]. However, the impact of ustekinumab on metabolic parameters is still unclear. According to $\mathrm{Ng}$ et al. in their study the levels of fasting glucose and triglyceride were elevated after 24 weeks of treatment with anti-interleukin 12/23 monoclonal antibody, while levels of cholesterol, LDL and HDL remained unchanged [61]. wskaźnikiem umożliwiającym wykrywanie NAFLD. Baran i wsp. stwierdzili istotny wzrost stężenia FABP1 w surowicy u pacjentów z łuszczycą w porównaniu ze zdrową grupą kontrolną [48]. Stężenie FABP1 istotnie się zmniejszyło po 12 tygodniach leczenia ogólnego metotreksatem (MTX) lub acytretyną. Badanie to wykazuje, że FABP1 może służyć jako biomarker łuszczycy i wyjaśniać potencjalną zależność pomiędzy chorobą skóry a wspótistniejącymi schorzeniami kardiometabolicznymi. Może mieć także dodatkową wartość przy ocenie odpowiedzi na leczenie przeciwłuszczycowe [48].

\section{UPOŚLEDZENIE CZYNNOŚCI WACTROBY WYWOŁANE LECZENIEM PRZECIWŁUSZCZYCOWYM}

Polekowe uszkodzenie wątroby jest główną przyczyną przeszczepienia wątroby ze wskazań nagłych. Może wykazywać zróżnicowany przebieg - od bezobjawowego podwyższenia aktywności enzymów wątrobowych po ostrą niewydolność tego narządu [3]. Obecność chorób wątroby u pacjentów z łuszczycą ogranicza możliwości terapeutyczne i narzuca konieczność ścisłego monitorowania funkcji wątroby. Niektóre leki ogólne mogą szczególnie niekorzystnie wpływać na czynność tego narządu. Podwyższona aktywność enzymów wątrobowych u pacjentów z łuszczycą wiąże się w 57\% przypadków z przyjmowaniem leków wykazujących toksyczny wpływ na wątrobę, a w 22\% przypadków ze współistniejącą NAFLD [51].

Jednym z najczęstszych skutków ubocznych leczenia MTX jest hepatotoksyczność [52]. Ryzyko upośledzenia czynności wątroby jest niskie u pacjentów bez współistniejących chorób tego narządu (takich jak wirusowe zapalenie wątroby typu B lub C), nienadużywających alkoholu oraz nieprzyjmujących innych leków hepatotoksycznych [52]. MTX rzadko wywołuje klinicznie istotną hepatotoksyczność, a u większości pacjentów aktywność enzymów wątrobowych jest tylko nieznacznie podwyższona [53]. Jednak u pacjentów z otyłością, cukrzycą typu 2 i NAFLD stosowanie MTX wymaga szczególnej ostrożności ze względu na wysokie ryzyko wystąpienia polekowego zwłóknienia wątroby. Ryzyko to jest znacznie wyższe u pacjentów z łuszczycą i współistniejącymi zaburzeniami metabolicznymi w porównaniu z pacjentami z łuszczycą bez współistniejących schorzeń metabolicznych [52]. Ryzyko hepatotoksyczności i zwłóknienia wątroby indukowane leczeniem MTX jest wyższe u pacjentów z łuszczycą niż u osób z reumatoidalnym zapaleniem stawów ze względu na ich większą podatność na rozwój zespołu metabolicznego [54].

Kolejnym lekiem, który może działać hepatotoksycznie, jest acytretyna, zwłaszcza u pacjentów nadużywających alkoholu lub przyjmujących inne leki hepatotoksyczne [52]. Acytretyna jest lekiem o działaniu 
Psoriatic patients with liver dysfunction should be treated according to general recommendations for NAFLD (weight reduction, physical activity and abstinence from alcohol consumption) to avoid further liver damage [26] (fig. 1).

\section{OTHERS LIVER DISEASES ASSOCIATED WITH PSORIASIS}

\section{Hepatitis B virus infection}

The association of psoriasis and HBV infection is indirect and it relies on the risk of $\mathrm{HBV}$ reactivation (HBVr) during immunosuppressive drug therapy (ISDT). However, there are some reports that HBV infection may induce or exacerbate psoriasis progress and hepatitis B virus can be detected in skin lesions [62]. hiperlipemicznym wywołującym zaburzenia w zakresie parametrów biochemicznych wątroby u $25 \%$ pacjentów [26]. Hepatotoksyczność wywołana cyklosporyną A występuje bardzo rzadko [53], niemniej lek należy stosować ostrożnie u pacjentów z łuszczycą i współistniejącymi zaburzeniami metabolicznymi. Cyklosporyna A może powodować zaostrzenie nadciśnienia tętniczego i nasilenie cukrzycy typu 2. Może również predysponować do aterogennej dyslipidemii i hiperurykemii [55]. Zarówno leczenie acytretyną, jak i cyklosporyną wiąże się ze wzrostem stężenia cholesterolu i trójglicerydów, natomiast acytretyna dodatkowo podwyższa ryzyko wystąpienia hipertrójglicerydemii [9].

Uważa się, że estry kwasów fumarowych (fumaric acid esters - FAE) i apremilast nie mają działania hepatotoksycznego. Leczenie FAE wiąże się jednak z powszechnym występowaniem zdarzeń niepożądanych, które są

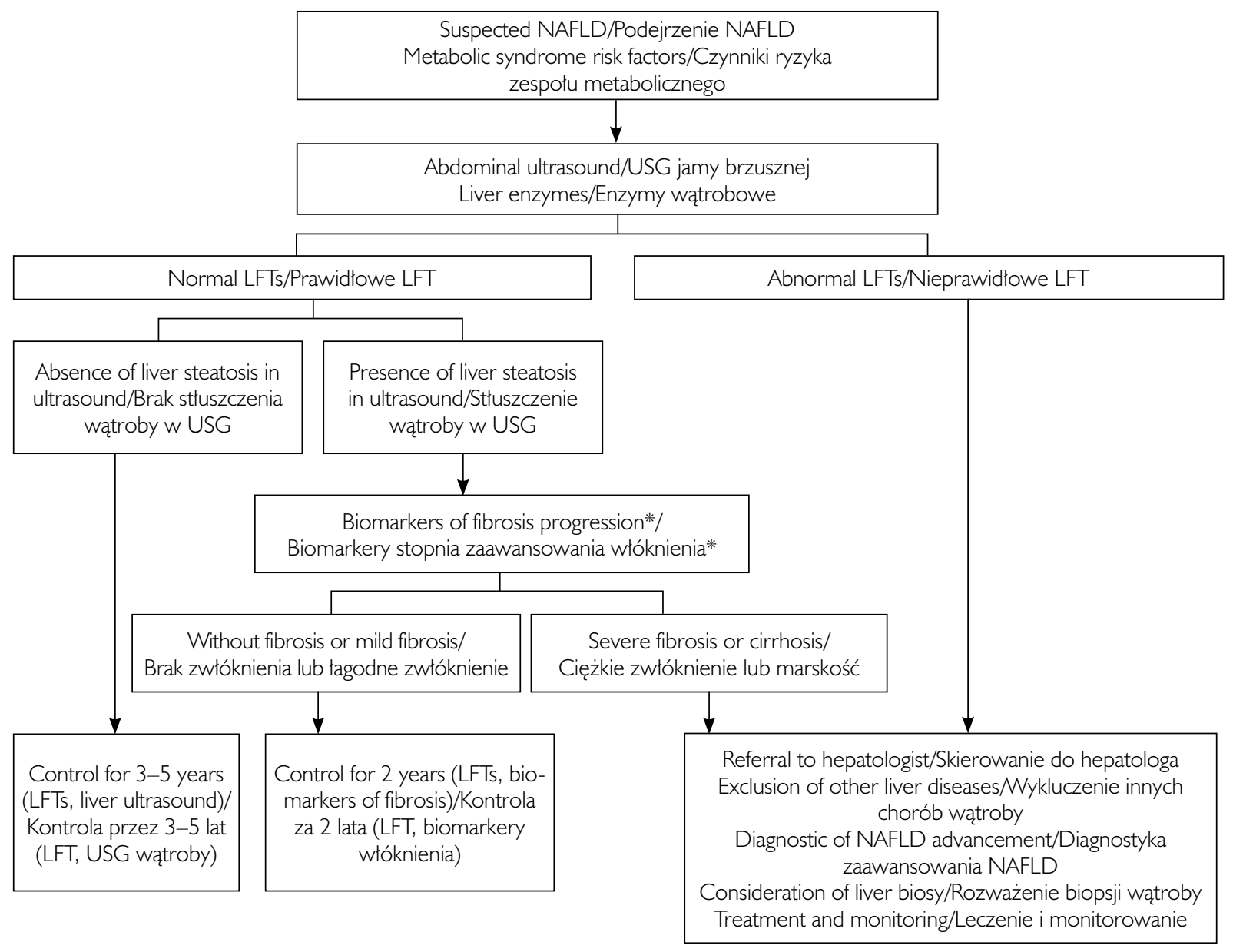

Figure I. The algorithm of diagnosis and management of nonalcoholic fatty liver disease. Adapted from clinical guidelines (EASL, EASD iEASO 2016)

*NAFLD fibrosis score, LFTs - liver function tests.

Rycina I. Algorytm diagnostyki i postępowania w niealkoholowej stłuszczeniowej chorobie wątroby. Dane pochodzą z klinicznych wytycznych postępowania w NAFLD (EASL, EASD i EASO 2016)

*Skala włóknienia NAFLD, LFTs - testy oceniające funkcję wątroby. 
Psoriatic patients should be screened for hepatitis B virus before starting immunosuppressive therapy with conventional disease-modifying drugs or biological agents. During the active phase of the infection systemic immunosuppressive anti-psoriatic treatment should be avoided. The therapy can be started after the proper control of HBV infection using anti-HBV drugs [63]. Independently of type of infection among psoriatic patients, the sudden reactivation of HBV after starting immunosuppressive treatment can be observed [64]. The highest risk of reactivation is observed among the inactive carriers, and the lowest risk is in resolved HBV infections [65].

The treatment of psoriatic patients with coexisting HBV infection should be carried out in close cooperation between a dermatologist and a hepatologist. According to the guidelines of experts of the Polish Dermatological Society cyclosporine $\mathrm{A}$ is relatively contraindicated in liver diseases and strictly contraindicated in patients with severe liver damage and MTX is strictly contraindicated in hepatitis B. Other literature data suggest that cyclosporine A is associated with a moderate risk of HBV reactivation, whereas MTX is associated with low risk of HBV reactivation [52]. However, the use of TNF- $\alpha$ inhibitors is associated with a very high risk of reactivation $\mathrm{HBV}$ infection [64].

\section{Hepatitis $C$ virus infection}

$\mathrm{HCV}$ infection was proved as a potentially infectious trigger of psoriasis in genetically predisposed patients $[66,67]$. Moreover, the late occurrence of psoriasis can be caused by HCV and the risk is double compared with noninfected individuals [68]. However, little is known about the role of viral infection in patients with already diagnosed psoriasis. There is also a very important role of TNF- $\alpha$ cytokine in HCV psoriatic patients in causing progression of hepatic disease and at the same time inducing psoriasis in predisposed cases [69].

$\mathrm{HCV}$ reactivation occurs extremely rarely after administration of immunosuppressive anti-psoriatic drugs, but they still have hepatotoxic properties. Among conventional methods of therapy acitretin and cyclosporine A are two possible options for treatment of psoriatic patients with $\mathrm{HCV}$ infection [70]. TNF- $\alpha$ inhibitors are believed to be a safe and effective option for HCV positive psoriatic patients, but there are some apprehensions with regard to their long-term use, the impact on progression of liver fibrosis and risk of developing immune-mediated liver injury. MTX due to its hepatotoxic effect is generally contraindicated and should not be used in these patients [71, 72]. zgłaszane nawet przez 2/3 pacjentów. Do najczęstszych należą objawy ze strony układu pokarmowego obejmujące ból brzucha, biegunkę, nudności i złe samopoczucie. Rzadko obserwuje się podwyższenie aktywności enzymów wątrobowych i stężenia bilirubiny [56].

Leki biologiczne na ogół nie mają negatywnego wpływu na parametry metaboliczne ani stężenie enzymów wątrobowych w surowicy [9]. Inhibitory TNF- $\alpha$ nie powodują klinicznie istotnego pogorszenia profilu lipidowego i zmniejszają ryzyko rozwoju cukrzycy typu 2. Campanati i wsp. w badaniu obejmującym 89 osób stwierdzili istotne zmniejszenie stosunku stężenia aminotransferazy asparaginianowej (AspAT) do aminotransferazy alaninowej (AlAT) oraz zmniejszenie stężenia CRP w surowicy i insuliny na czczo po 24 tygodniach leczenia etanerceptem [57]. W innym badaniu wykazano, że etanercept powoduje znaczące zmniejszenie stężenia glukozy na czczo po 6 miesiącach terapii. Profil lipidowy w surowicy pacjentów w przebiegu prowadzonego leczenia nie zmienił się [58]. Jednak w niektórych badaniach klinicznych u pacjentów z łuszczycą przyjmujących ten lek obserwowano działanie toksyczne na wątrobę. Podwyższone stężenie AspAT i AlAT stwierdzano nawet u 8\% pacjentów [59]. Dane pochodzące z 3 kontrolowanych badań z randomizacją obejmujących 52 tygodnie leczenia przeciwciałem monoklonalnym blokującym interleukinę 17 wskazują na stabilne stężenia enzymów wątrobowych. Według aktualnych doniesień sekukinumab nie oddziałuje na parametry lipidowe, takie jak TG, cholesterol, HDL i LDL [60]. Wpływ ustekinumabu na parametry metaboliczne jest nieznany. W badaniu Ng i wsp. stężenia glukozy na czczo i TG były podwyższone po 24 tygodniach leczenia monoklonalnym przeciwciałem skierowanym przeciwko interleukinie 12/23. Nie stwierdzono natomiast zmian w stężeniach cholesterolu, LDL i HDL [61].

Pacjenci z łuszczycą, u których występuje upośledzenie czynności wątroby, powinni być leczeni zgodnie z ogólnymi zaleceniami dotyczącymi terapii NAFLD (zmniejszenie masy ciała, aktywność fizyczna i rezygnacja ze spożywania alkoholu), aby uniknąć dalszego uszkodzenia wątroby [26] (ryc. 1).

\section{INNE CHOROBY WĄTROBY ZWIAZZANE $Z$ ŁUSZCZYCA}

\section{Zakażenie wirusem zapalenia wątroby typu B}

Zależność między łuszczycą a zakażeniem wirusem HBV ma charakter pośredni i obejmuje ryzyko reaktywacji wirusa (HBVr) podczas terapii lekami immunosupresyjnymi (immunosuppressive drug therapy - ISDT). Istnieją jednak doniesienia, że zakażenie to może indukować lub zaostrzać przebieg łuszczycy, a wirus HBV może być wykrywany w zmianach skórnych [62].

Pacjenci z łuszczycą powinni być badani przesiewowo w kierunku zakażenia wirusem zapalenia wątroby typu B przed rozpoczęciem leczenia immunosupresyjnego kon- 


\section{Autoimmune liver diseases}

Autoimmune liver diseases are associated with many extrahepatic autoimmune disturbances, among other skin diseases. Psoriasis, lichen planus and vitiligo are the most common skin manifestations which may coexist with autoimmune liver diseases [73]. These autoimmune disorders can occur together and create the overlap syndrome and constitute a "mosaic of autoimmunity" coexisting with other autoimmune diseases, especially psoriasis [74]. The prevalence of psoriasis in primary biliary cirrhosis (PBC) patients is about $13 \%$ [75] and the risk of developing PBC in those patients is much higher than in healthy individuals [76].

Autoimmune hepatitis related to anti-TNF therapy is rare; despite this, it is recommended to perform a baseline immunological panel along with liver function tests in all patients with autoimmune disease before starting biologics. Rodrigues et al. in their research reported 8 cases of patients out of 600 who developed AIH associated with anti-TNF agents. Those patients were treated with infliximab, adalimumab and etanercept for inflammatory bowel disease, autoimmune rheumatological and dermatological disease [77].

\section{Hepatocellular carcinoma}

The association of hepatocellular carcinoma (HCC) and psoriasis is still unknown but there is some evidence that the same pro-inflammatory cytokines such as IL- 6 and TNF- $\alpha$ may play a pivotal role in the development of psoriasis and of liver cancer [3]. Interleukin-6 signals through two distinct pathways: the IL-6 classic and the IL-6 trans-signaling pathway. IL-6 trans-signaling is relevant to promote hepatocellular carcinogenesis. Moreover, this pathway directly provokes endothelial cell proliferation, contributing to tumor angiogenesis [78]. An increased level of TNF- $\alpha$ results in development of hepatic steatosis and inflammation within the liver and subsequently promotes the development of HCC [79].

HCC can also be indirectly associated with psoriasis. As it was mentioned previously psoriasis is associated with many liver dysfunctions which can lead to HCC. Among others there is a high risk of development of HCC in the course of NAFLD or hepatitis B and C. Moreover, it is believed that obesity and overweight, which coexist with psoriasis, are also associated with higher risk of HCC. These components of metabolic syndrome increase the prevalence of HCC in the general population [79].

\section{CONCLUSIONS}

There is a strong connection between psoriasis and liver dysfunction. However, psoriatic patients wencjonalnymi lekami modyfikującymi przebieg choroby lub lekami biologicznymi. W aktywnej fazie zakażenia należy unikać ogólnoustrojowego immunosupresyjnego leczenia przeciwłuszczycowego. Terapię można rozpocząć po opanowaniu zakażenia HBV za pomocą leków przeciw wirusowemu zapaleniu wątroby typu B [63]. Niezależnie od rodzaju zakażenia u pacjentów z łuszczycą można zaobserwować nagłą reaktywację HBV po rozpoczęciu leczenia immunosupresyjnego [64]. Najwyższe ryzyko reaktywacji dotyczy nieaktywnych nosicieli, a najniższe jest związane $\mathrm{z}$ wyleczonymi zakażeniami HBV [65].

Leczenie pacjentów z łuszczycą i współistniejącym zakażeniem HBV wymaga ścisłej współpracy dermatologa i hepatologa. Zgodnie z wytycznymi opracowanymi przez grupę ekspertów Polskiego Towarzystwa Dermatologicznego cyklosporyna A jest lekiem względnie przeciwwskazanym u pacjentów z chorobami wątroby i bezwzględnie przeciwwskazanym u osób z ciężkim uszkodzeniem wątroby. MTX jest bezwzględnie przeciwwskazany w leczeniu pacjentów z zapaleniem wątroby typu B. Inne dane z piśmiennictwa sugerują, że leczenie cyklosporyną A wiąże się z umiarkowanym ryzykiem, a terapia MTX z niskim ryzykiem reaktywacji HBV [52]. Stosowanie inhibitorów TNF- $\alpha$ jest $z$ kolei powiązane $\mathrm{z}$ bardzo wysokim ryzykiem reaktywacji zakażenia HBV [64].

\section{Zakażenie wirusem zapalenia wątroby typu C}

Udowodniono, że zakażenie HCV jest potencjalnym czynnikiem inicjującym rozwój łuszczycy u pacjentów z predyspozycją genetyczną $[66,67]$. Ponadto infekcja HCV może prowokować łuszczycę o późnym początku, a ryzyko w tym przypadku jest dwukrotnie wyższe niż u osób niezakażonych HCV [68]. Niewiele jednak wiadomo na temat wpływu zakażenia wirusem u pacjentów z już rozpoznaną łuszczycą. Bardzo istotny jest również udział cytokiny TNF- $\alpha$ u pacjentów z łuszczycą i zakażeniem HCV w indukowaniu progresji choroby wątroby i jednocześnie wywoływaniu łuszczycy u pacjentów z występującą predyspozycją [69].

Reaktywacja HCV po podaniu immunosupresyjnych leków przeciwłuszczycowych jest zjawiskiem niezwykle rzadkim, jednak trzeba mieć na uwadze, że środki te mają właściwości hepatotoksyczne. Wśród konwencjonalnych metod leczenia pacjentów z łuszczycą i zakażeniem HCV należy wymienić acytretynę i cyklosporynę A [70]. Uważa się, że inhibitory TNF- $\alpha$ są bezpieczną i skuteczną opcją leczenia pacjentów z łuszczycą i dodatnim wynikiem na obecność wirusa HCV, choć istnieją pewne obawy dotyczące długotrwałego stosowania leków z tej grupy, ich wpływu na progresję zwłóknienia wątroby i ryzyko immunologicznego uszkodzenia wątroby. Ze względu na działanie hepatotoksyczne MTX jest jednak zasadniczo przeciwwskazany w tej grupie pacjentów i nie powinien być stosowany [71,72]. 
can develop different variants of liver disease, the most common being NAFLD. Both diseases share the same molecular mechanisms: chronic systemic inflammation, oxidative stress, disturbances of lipid metabolism, immune pathways and secretions of bioactive molecules. Due to the higher risk of cardiovascular events, psoriatic patients with liver dysfunction should be carefully assessed by both dermatologists and hepatologists. Fast detection of liver disorders among those patients and implementation of prophylaxis such as physical activity, weight reduction and limited alcohol consumption will reduce the number of liver failures and also allow other related metabolic disturbances to be avoided.

\section{CONFLICT OF INTEREST}

The authors declare no conflict of interest.

\section{Autoimmunologiczne choroby wątroby}

Autoimmunologicznym chorobom wątroby może towarzyszyć szerokie spektrum pozawątrobowych zaburzeń autoimmunologicznych, m.in. choroby skóry. Do najczęstszych schorzeń skórnych, które mogą współistnieć $\mathrm{z}$ autoimmunologicznymi chorobami wątroby, należą: łuszczyca, liszaj płaski i bielactwo [73]. Wymienione zaburzenia autoimmunologiczne mogą też występować łącznie, tworząc zespół nakładania się i tzw. mozaikę autoimmunizacji [74]. Częstość występowania łuszczycy u pacjentów z pierwotną marskością żółciową (primary biliary cirrhosis - PBC) wynosi 13\% [75], a ryzyko rozwoju PBC u tych pacjentów jest znacznie wyższe niż u osób zdrowych [76]

Autoimmunologiczne zapalenie wątroby związane z leczeniem anty-TNF występuje rzadko, jednak przed rozpoczęciem leczenia biologicznego zaleca się wykonanie wyjściowego panelu badań immunologicznych z oceną aktywności enzymów wątrobowych u wszystkich pacjentów z rozpoznaną chorobą autoimmunologiczną. Rodrigues i wsp. $\mathrm{w}$ badaniach $\mathrm{w}$ grupie 600 pacjentów stwierdzili 8 przypadków autoimmunologicznego zapalenia wątroby związanego z przyjmowaniem leków anty-TNF. Pacjenci objęci badaniem byli leczeni infliksymabem, adalimumabem i etanerceptem $z$ powodu choroby zapalnej jelit, autoimmunologicznej choroby reumatologicznej i choroby dermatologicznej [77].

\section{Rak wątrobowokomórkowy}

Zależność między rakiem wątrobowokomórkowym (hepatocellular carcinoma - HCC) a łuszczycą nie została dotąd jednoznacznie potwierdzona, jednak istnieją dowody, że te same cytokiny prozapalne (m.in. IL-6 i TNF- $\alpha$ ), mogą odgrywać kluczową rolę zarówno w rozwoju łuszczycy, jak i raka wątroby [3]. Sygnały IL-6 są przekazywane przez dwa odrębne szlaki: klasyczny szlak sygnałowy IL-6 i szlak transsygnałowy IL-6. Transsygnalizacja IL-6 jest istotna w procesie kancerogenezy HCC. Ponadto szlak ten bezpośrednio wywołuje proliferację komórek śródbłonka, co przyczynia się do angiogenezy nowotworu [78]. Podwyższone stężenie TNF- $\alpha$ prowadzi do stłuszczenia wątroby i stanu zapalnego w obrębie tego narządu, co z kolei sprzyja rozwojowi HCC [79].

Rak wątrobowokomórkowy może mieć również pośredni związek z łuszczycą. Jak już wcześniej wspomniano, istnieje zależność między łuszczycą a licznymi zaburzeniami czynności wątroby, które mogą prowadzić do rozwoju HCC, szczególnie w przebiegu NAFLD powikłanej marskością lub zapalenia wątroby typu B i C. Uważa się ponadto, że otyłość i nadwaga, które współistnieją z łuszczyca, dodatkowo zwiększają ryzyko wystąpienia HCC. Powyższe komponenty zespołu metabolicznego zwiększają częstość występowania HCC w populacji ogólnej [79]. 
Istnieje silna zależność między łuszczycą a upośledzeniem czynności wątroby. U pacjentów z łuszczycą mogą występować różne schorzenia tego narządu, wśród których najczęściej stwierdza się NAFLD. Obie choroby charakteryzują się podobnym mechanizmem molekularnym, takim jak przewlekłe zapalenie ogólnoustrojowe, stres oksydacyjny, zaburzenia metabolizmu lipidów, wspólne szlaki immunologiczne oraz wydzielanie cząsteczek bioaktywnych. Ze względu na podwyższone ryzyko występowania incydentów sercowo-naczyniowych pacjenci z łuszczycą i zaburzeniami czynności wątroby wymagają ścisłej obserwacji zarówno przez dermatologa, jak i hepatologa. Wczesne wykrywanie zaburzeń czynności wątroby wśród tych pacjentów oraz wdrażanie odpowiedniej profilaktyki, obejmującej m.in. wzrost aktywności fizycznej, redukcję masy ciała i ograniczenie spożycia alkoholu, umożliwia zmniejszenie liczby przypadków niewydolności wątroby i pozwala uniknąć innych powiązanych zaburzeń metabolicznych.

\section{KONFLIKT INTERESÓW}

Autorzy nie zgłaszają konfliktu interesów.

\section{References}

\section{Piśmiennictwo}

1. Boehncke W.H., Schön M.P.: Psoriasis. Lancet 2015, 386, 983-994.

2. Burfield L., Burden A.D.: Psoriasis. J R Coll Physicians Edinb 2013, 43, 334-338.

3. Fiore M., Leone S.,Maraolo A.E., Berti E., Damiani G.: Liver illness and psoriatic patients. Biomed Res Int 2018, 2018, 3140983.

4. Parisi R., Symmons D.P.M., Griffiths C.E.M., Ashcroft D.M.: Global epidemiology of psoriasis: a systematic review of incidence and prevalence. J Inv Dermatol 2013, 133, 377-385.

5. Sales R., Torres T.: Psoriasis and metabolic syndrome. Acta Dermatovenerol Croat 2014, 22, 169-174.

6. Weigle N., McBane S.: Psoriasis. Am Fam Physician 2013, 87, 626-633.

7. Owczarczyk-Saczonek A., Nowicki R.: Pathophysiology of the relationship of psoriasis and metabolic disorders. Dermatol Rev 2013, $100,125-131$.

8. Ganzetti G., Campanati A., Offidani A.: Non-alcoholic fatty liver disease and psoriasis: so far, so near. World J Hepatol 2015, 7, 315326.

9. Mantovani A., Gisondi P., Lonardo A., Targher G.: Relationship between non-alcoholic fatty liver disease and psoriasis: a novel hepato-dermal axis? Int J Mol Sci 2016, 17, 217.

10. Blachier M., Leleu H., Peck-Radosavljevic M., Valla D.C., Roudot-Thoraval F.: The burden of liver disease in Europe: a review of available epidemiological data. J Hepatol 2013, 58, 593-608.

11. Byrne C.D., Targher G.: NAFLD: a multisystem disease. J Hepatol 2015, 62, 47-64.

12. Sakkas L.I., Bogdanos D.P.: Are psoriasis and psoriatic arthritis the same disease? The IL-23/IL-17 axis data. Autoimmun Rev 2017, $16,10-15$.

13. Mikolasevic I., Milic S., Wensveen T.T., Grgic I., Jakopcic I., Stimac D., et al.: Nonalcoholic fatty liver disease - a multisystem disease? World J Gastroenterol 2016, 22, 9488-9505.

14. Pietrzak D., Pietrzak A., Krasowska D., Borzęcki A., Franciszkiewicz-Pietrzak K.. Polkowska-Pruszyńska B., et al.: Digestive system in psoriasis: an update. Arch Dermatol Res 2017, 309, 679-693.

15. Madanagobalane S., Anandan S.: The increased prevalence of non-alcoholic fatty liver disease in psoriatic patients: a study from South India. Australas J Dermatol 2012, 53, 190-197.

16. Abedini R., Salehi M., Lajevardi V., Beygi S.: Patients with psoriasis are at a higher risk of developing nonalcoholic fatty liver disease. Clin Exp Dermatol 2015, 40, 722-727.

17. Gisondi P., Targher G., Zoppini G., Girolomoni G.: Non-alcoholic fatty liver disease in patients with chronic plaque psoriasis. J Hepatol 2009, 51, 758-764.

18. Narayanasamy K., Sanmarkan A.D., Rajendran K., Rajendran C., Ramalingam S.: Relationship between psoriasis and non-alcoholic fatty liver disease. Gastroenterol Rev 2016, 11, 263-269. 
19. Van der Voort E.A., Koehler E.M., Dowlatshahi E.A., Hofman A., Stricker B.H., Janssen H.L., et al.: Psoriasis is independently associated with nonalcoholic fatty liver disease in patients 55 years old or older: results from a population-based study. J Am Acad Dermatol 2014, 70, 517-524.

20. Roberts K.K., Cochet A.E., Lamb P.B., Brown P.J., Battafarano D.F., Brunt E.M., et al.: The prevalence of NAFLD and NASH among patients with psoriasis in a tertiary care dermatology and rheumatology clinic. Aliment Pharmacol Ther 2015, 41, $293-300$.

21. Candia R., Ruiz A., Torres-Robles R., Chávez-Tapia N., Méndez-Sánchez N., Arrese M.: Risk of non-alcoholic fatty liver disease in patients with psoriasis: a systematic review and meta-analysis. J Eur Acad Dermatol Venereol 2015, $29,656-662$.

22. Ganzetti G., Campanati A., Molinelli E., Offidani A.: Psoriasis, non-alcoholic fatty liver disease, and cardiovascular disease: three different diseases on a unique background. World J Cardiol 2016, 8, 120-131.

23. Barak V., Selmi C., Schlesinger M., Blank M., Agmon-Levin N., Kalickman I., et al.: Serum inflammatory cytokines, complement components, and soluble interleukin 2 receptor in primary biliary cirrhosis. J Autoimmun 2009, 33, 178-182.

24. Harada K., Shimoda S., Sato Y., Isse K., Ikeda H., Nakanuma Y.: Periductal interleukin-17 production in association with biliary innate immunity contributes to the pathogenesis of cholangiopathy in primary biliary cirrhosis. Clin Exp Immunol 2009, 157, 261-270.

25. Miele L., Vallone S., Cefalo C., La Torre G., Di Stasi C., Vecchio F.M., et al.: Prevalence, characteristics and severity of non-alcoholic fatty liver disease in patients with chronic plaque psoriasis. J Hepatol 2009, 51, 778-786.

26. Olveira A., Herranz P., Montes M.L.: Psoriasis and fatty liver: a harmful synergy. Rev Esp Enferm Dig 2019, 111, 314-319.

27. Treeprasertsuk S., Björnsson E., Enders F., Suwanwalaikorn S., Lindor K.D.: NAFLD fibrosis score: a prognostic predictor for mortality and liver complications among NAFLD patients. World J Gastroenterol 2013, 19, 1219-1229.

28. Balato N., Napolitano M., Ayala F., Patruno C., Megna M., Tarantino G.: Nonalcoholic fatty liver disease, spleen and psoriasis: new aspects of low-grade chronic inflammation. World J Gastroenterol 2015, 21, 6892-6897.

29. Ganzetti G., Campanati A., Offidani A.: Non-alcoholic fatty liver disease and psoriasis: so far, sonear. World J Hepatol 2015, 7, 315-326.

30. Wasilewska N., Bobrus-Chociej A., Harasim-Symbor E., Tarasów E., Wojtkowska M., Chabowski A., et al.: Increased serum concentration of ceramides in obese children with nonalcoholic fatty liver disease. Lipids Health Dis 2018, 17, 216.

31. Wenk K.S., Arrington K.C.: Psoriasis and non-alcoholic fatty liver disease. J Eur Acad Dermatol Venereol 2011, $25,282-391$.

32. Chehimi M., Vidal H., Eljaafari A.: Pathogenic role of IL-17-producing immune cells in obesity, and related inflammatory diseases. J Clin Med 2017, 6, 68 .

33. Hunter C.A., Jones S.A.: IL-6 as a keystone cytokine in health and disease. Nat Immunol 2015, 16, 448-457.

34. Baran A., Kiluk P., Myśliwiec H., Flisiak I.: The role of lipids in psoriasis. Dermatol Rev 2017, 104, 619-635.

35. Myśliwiec H., Baran A., Harasim-Symbor E., Myśliwiec P., Milewska A.J., Chabowski A., et al.: Serum fatty acid profile in psoriasis and its comorbidity. Arch Dermatol Res 2017, 309, 371-380.

36. Pietrzak A., Chabros P., Grywalska E., Kiciński P., Pietrzak-Franciszkiewicz K., Krasowska D., et al.: Serum lipid metabolism in psoriasis and psoriatic arthritis - an update. Arch Med Sci 2019, 15, 369-375.

37. Borodzicz S., Rudnicka L., Mirowska-Guzel D., Cudnoch-Jędrzejewska A.: The role of epidermal sphingolipids in dermatologic diseases. Lipids Health Dis 2016, 15, 13.

38. Myśliwiec H., Baran A., Harasim-Symbor E., Choromańska B., Myśliwiec P., Milewska A.J., et al.: Increase in circulating sphingosine-1-phosphate and decrease in ceramide levels in psoriatic patients. Arch Dermatol Res 2017, 309, 79-86.

39. Chaurasia B., Summers S.A.: Ceramides - lipotoxic inducers of metabolic disorders. Trends Endocrinol Metab 2015, 26, 538-550.

40. Kurek K., Piotrowska D.M., Wiesiołek-Kurek P., Łukaszuk B., Chabowski A., Górski J., et al.: Inhibition of ceramide de novo synthesis reduces liver lipid accumulation in rats with nonalcoholic fatty liver disease. Liver Int 2014, 34, 1074-1083.

41. Maldonado-Hernández J., Saldaña-Dávila G.E., Piña-Aguero M.I., Núñez-García B.A., López-Alarcón M.G.: Association between plasmatic ceramides profile and AST/ALT ratio: C14:0 ceramide as predictor of hepatic steatosis in adolescents independently of obesity. Can J Gastroenterol Hepatol 2017, 2017, 3689375.

42. Herbert D., Franz S., Popkova Y., Anderegg U., Schiller J., Schwede K., et al.: High fat diet exacerbates early psoriatic skin inflammation independent of obesity: saturated fatty acids as key players. J Invest Dermatol 2018, 138, 1999-2009.

43. Kendall A.C., Kiezel-Tsugunova M., Brownbridge L.C., Harwood J.L., Nicolaou A.: Lipid functions in skin: differential effects of n-3 polyunsaturated fatty acids on cutaneous ceramides, in a human skin organ culture model. Biochem Biophys Acta 2017, 1859, 16791689.

44. O'Mahoney L.L., Matu J., Price O.J., Birch K.M., Ajjan R.A., Farrar D., et al.: Omega-3 polyunsaturated fatty acids favourably modulate cardiometabolic biomarkers in type 2 diabetes: a meta-analysis and meta-regression of randomized controlled trials. Cardiovasc Diabetol 2018, 17, 98

45. Jańczyk W., Socha P., Lebensztejn D., Wierzbicka A., Mazur A., Neuhoff-Murawska J., et al.: Omega-3 fatty acids for treatment of non-alcoholic fatty liver disease: design and rationale of randomized controlled trial. BMC Pediatr 2013, 13, 85.

46. Zhang Y., Li B.: E-FABP: regulator of immune function. Oncoscience 2014, 1, 398-399.

47. Baran A., Świderska M., Bacharewicz-Szczerbicka J., Myśliwiec H., Flisiak I.: Serum fatty acid binding protein 4 is increased in patients with psoriasis. Lipids 2017, 52, 51-60.

48. Baran A., Kiluk P., Maciaszek M., Świderska M., Flisiak I.: Liver fatty acid-binding protein might be a predictive marker of clinical response to systemic treatment in psoriasis. Arch Dermatol Res 2019, 311, 389-397.

49. Gajda A.M., Storch J.: Enterocyte fatty acid-binding proteins (FABPs): different functions of liver and intestinal FABPs in the intestine. Prostaglandins Leukot Essent Fatty Acids 2015, 93, 9-16.

50. Furuhashi M., Ishimura S., Ota H., Hayashi M., Nishitani T., Tanaka M., et al.: Serum fatty acid-binding protein 4 is a predictor of cardiovascular events in end-stage renal disease. PLoS One 2011, 6, e27356.

51. Tula E., Ergun T., Seckin D., Ozgen Z., Avsar E.: Psoriasis and the liver: problems, causes and course. Austral J Dermatol 2017, 58, 194-199.

52. Reich A., Szepietowski J., Adamski Z., Chodorowska G., Kaszuba A., Krasowska D., et al.: Psoriasis. Diagnostic and therapeutic recommendations of the Polish Dermatological Society. Part II: Moderate to severe psoriasis. Dermatol Rev 2018, 105, 329-357.

53. Helliwell P.S., Taylor W.J.: Treatment of psoriatic arthritis and rheumatoid arthritis with disease modifying drugs - comparison of drugs and adverse reactions. J Rheumatol 2008, 35, 472-476. 
54. Prussick R.B., Miele L.: Non alcoholic fatty liver disease in patients with psoriasis: a consequence of systemic inflammatory burden? Br J Dermatol 2018, 179, 16-29.

55. Tobon G.J., Cañas C., Jaller J.J., Restrepo J.C., Anaya J.M.: Serious liver disease induced by infliximab. Clin Rheumatol 2007, 26, 578581.

56. Roll A., Reich K., Boer A.: Use of fumaric acid esters in psoriasis. Indian J Dermatol Venereol Leprol 2007, 73, 133-137.

57. Campanati A., Ganzetti G., Di Sario A., Damiani A., Sandroni L., Rosa L., et al.: The effect of etanercept on hepatic fibrosis risk in patients with non-alcoholic fatty liver disease, metabolic syndrome, and psoriasis. J Gastroenterol 2013, 48, 839-46.

58. Stanley T.L., Zanni M.V., Johnsen S., Rasheed S., Makimura H., Lee H., et al.: TNF-alpha antagonism with etanercept decreases glucose and increases the proportion of high molecular weight adiponectin in obese subjects with features of the metabolic syndrome. J Clin Endocrinol Metab 2011, 96, 146-150.

59. Prussick R.B., Miele L.: Nonalcoholic fatty liver disease in patients with psoriasis: a consequence of systemic inflammatory burden? Br J Dermatol 2018, 179, 16-29.

60. Gerdes S., Pinter A., Papavassilis C., Reinhardt M.: Effects of secukinumab on metabolic and liver parameters in plaque psoriasis patients. J Eur Acad Dermatol Venereol 2020, 34, 533-541.

61. Ng C.Y., Tzeng I.S., Liu S.H., Chang Y.C., Huang Y.H.: Metabolic parameters in psoriatic patients treated with interleukin-12/23 blockade (ustekinumab). J Dermatol 2018, 45, 309-313.

62. Lin Z., Guo-Sheng D., Li-Chao P., Yong-Gen Z., Zhi-Jia L., Hai-Da S., et al.: Sirolimus treatment for cirrhosis or hepatocellular carcinoma patients accompanied by psoriasis after liver transplantation: a single center experience. Oncol Lett 2017, 14, 7817-7824

63. Nast A., Gisondi P., Ormerod A.D., Saiag P., Smith C., Spuls P.I., et al.: European S3 Guidelines on the systemic treatment of psoriasis vulgaris. J Eur Acad Dermatol Venereol 2015, 29, 2277-2294.

64. Hoofnagle J.H.: Reactivation of hepatitis B. Hepatology 2009, 49, 156-165.

65. Cantini F., Boccia S., Goletti D., Iannone F., Leoncini E., Panic N., et al.: HBV reactivation in patients treated with antitumor necrosis factor-alpha (TNF-alpha) agents for rheumatic and dermatologic conditions: a systematic review and meta-analysis. Int J Rheumatol 2014, 2014, 926836.

66. Cacoub P., Gragnani L., Comarmond C., Zignego A.L.: Extrahepatic manifestations of chronic hepatitis C virus infection. Dig Liver Dis 2014, 46, 165-173.

67. Bogdanos D.P., Sakkas L.I.: From microbiome to infectome in autoimmunity. Curr Opin Rheumatol 2017, $29,369-373$.

68. Imafuku S., Naito R., Nakayama J.: Possible association of hepatitis C virus infection with late-onset psoriasis: a hospital-based observational study. J Dermatol 2013, 40, 813-818.

69. Imafuku S., Nakayama J.: Profile of patients with psoriasis associated with hepatitis C virus infection. J Dermatol 2013, 40, $428-433$.

70. Miura H., Itoh Y., Matsumoto Y., Tani M., Tanabe N., Isonokami M., et al.: Long-term administration of cyclosporin A to HCV-antibody-positive patients with dermatologic diseases. Int J Dermatol 1999, 38, 310-314

71. Czarnecka-Operacz M., Sadowska-Przytocka A.: The possibilities and principles of methotrexate treatment of psoriasis - the updated knowledge. Adv Dermatol Allergol 2014, 31, 392-400.

72. Hsu S., Papp K.A., Lebwohl M.G., Bagel J., Blauvelt A., Duffin K.C., et al.: Consensus guidelines for the management of plaque psoriasis. Arch Dermatol 2012, 148, 95-102.

73. Terziroli Beretta-Piccoli B., Invernizzi P., Gershwin M.E., Mainetti C.: Skin manifestations associated with autoimmune liver diseases: a systematic review. Clin Rev Allergy Immunol 2017, 53, 394-412.

74. Efe C., Wahlin S., Ozaslan E., Berlot A.H., Purnak T., Muratori L., et al.: Autoimmune hepatitis/primary biliary cirrhosis overlap syndrome and associated extrahepatic autoimmune diseases. Eur J Gastroenterol Hepatol 2012, 24, $531-534$

75. Howel D., Fischbacher C.M., Bhopal R.S., Gray J., Metcalf J.V., James O.F.W.: An exploratory population-based case-control study of primary biliary cirrhosis. Hepatology 2000, 31, 1055-1060.

76. Prince M.I., Ducker S.J., James O.F.: Case-control studies of risk factors for primary biliary cirrhosis in two United Kingdom populations. Gut 2010, 59, 508-512.

77. Rodrigues S., Lopes S., Magro F., Cardoso H., Horta e Vale A.M., Marques M.: Autoimmune hepatitis and anti-tumor necrosis factor alpha therapy: a single center report of 8 cases. World J Gastroenterol 2015, 21, 7584-7588.

78. Bergmann J., Muller M., Baumann N., Reichert M., Heneweer C., Bolik J., et al.: IL-6 trans-signaling is essential for the development of hepatocellular carcinoma in mice. Hepatology 2017, 65, 89-103.

79. Desai A., Sandhu S., Lai J.P., Sandhu D.S.: Hepatocellular carcinoma in non-cirrhotic liver: a comprehensive review. World J Hepatol $2019,11,1-18$

Received: 25.07.2019

Accepted: 21.05 .2020

Otrzymano: 25.07.2019 r

Zaakceptowano: 21.05.2020 r.

How to cite this article

Kozłowska D., Myśliwiec H., Flisiak I.: Inflammation and lipid metabolism as a strong background connecting psoriasis and liver diseases. Dermatol Rev/Przegl Dermatol 2020, 107, 257-272. DOI: https://doi.org/10.5114/dr.2020.97819. 